\title{
AN ASSESSMENT OF THE CONVENTION FROM THE POINT OF THE CANDIDATE COUNTRIES ${ }^{*}$
}

\section{Ayfer Yumaz}

At the beginning of my speech, I would like to thank firstly the distinguished administrators of the European Community Institute of Marmara University that contributed to the hosting of this Conference within the framework of the May 9, Europe Day, and I would like to express my sincere respects to you all.

Today, as a member of Parliament who is participating in the Convention on behalf of our Parliament, I will try to provide an assessment of the EU Convention following the conclusion of its third meeting, within the framework of the developments and opinions which necessitated the Convention.

Today, both the stance of Europe and the Union towards the external world and the stance of the external world towards Europe as well as the Union is a result of the common historical relationship and cultural interactions which have existed for centuries.

Naturally, every kind of "union", according to the conditions in which it exists, is formed in opposition to a real and desired common "foreigner" and there is, desired or not, a distinction between "itself" and the "other".

Despite the fact that Europe, in the historical process, is founded on the values created by Christianity, the Enlightenment and the Industrial

* Speech for the international conference entitled "The Future of the European Union and Turkey" organized by the European Community Institute of Marmara University on the occassion of the Europe Day, 9 May 2002.

** Member the Grand National Assembly of Turkey. 
Revolution, the most important factor uniting the Europeans around these values was the element of "foreign or external threat."

The unification efforts initiated by Victor Hugo in the 19th Century, turned to be a conscious idea in the aftermath of the Second World War and the idea of the united States of Europe was presented by Churchill in 1946 to recover the wounds caused by the Second World War, not to encounter such a war again and at the same time, to establish a European Block opposed to the Soviet pressure under an American umbrella.

After the Schuman Declaration on the Foundation of the ECSC in 9 May 1950, the 1951 Paris and 1957 Rome Treaties which formed the community were signed by Belgium France, Germany, Italy, Luxemburg and the Netherlands.

The Community that completed a Customs Union in 1968 and modified the Founding Treaties extensively in 1987 by enacting the Single European Act. In this process, the number of member states reached 12 .

At the end of the 20th Century, the collapse of the Soviet Union and the Berlin Wall required the Community to reconsider its own future as well as of the Europe as a whole.

The perceptions of "threat" created by elements which had been excluded from globalization and the new world order, hot conflicts and strategic locations have become the reasons for the changing nature of the discussions about the Union and the current dynamics of reconstructing.

As a result of the Maastricht Treaty which entered into effect in 1993, the Community gained new dimensions. A new legal structure was defined by establishing three basic pillars; Economic and Monetary Union; Common Foreign and Security Policy and Cooperation in justice and home affairs.

A the Nice European Summit in 2000 in which the discussions about reform started a lack of consensus meant that issues such as determining the limits and distribution of authority between the EU and the member states, the status of the Charter of the Fundamental Rights, the role of the National Parliaments and the simplification of the founding treaties were delayed until the Inter-Governmental Conference to be held in 2004. 
While the 2001 Laeken Summit, discussed issues such as the Union's future, Euro, ESDP, Enlargement Process, Struggle against Terrorism, Economic and Social Development, Justice, Internal and Foreign Affairs, significant decisions as to the future of the Union were taken.

The final declaration stated it was necessary to form a convention based on the participation of government, Parliament, NGOs and youth to present views in the form of recommendation about these issues to the IGC, 2004. It was also emphasized that all the candidate countries could contribute to this Convention.

The question to be responded should be "What we want to do together". And the point to be careful is that the Convention should not be regarded as a platform where the limits for enlargement can be discussed.

The Maastricht Treaty of 1993 constituted the basis on which an economic community was transformed into a "Union" equipped with political powers.

The lack of necessary common positions by the EU member states towards the crisis in the Balkans, the difficulties they faced in the struggle against high employment, has caused a hesitation between loyalty to the notion of "nation state" and the will for a "Union".

When the current institutional structures and decision-making mechanisms even with fifteen members is considered as an element slowing down the functioning of the system, it is a matter of concern how a Union with twenty eight or even thirty members will be able to function in a democratic manner.

The EU is approaching the new millennium with a heavy agenda.

The EU institutions have problems in tackling an increasingly heavy work load.

Within this framework, the Union should define its weak points and should produce solutions for the same. 
The suspicion that the EU is not well administered, makes the masses feel mistrust towards its institutions, remain insensitive to its work or become sceptical regarding their future. Those feelings became the reason for the low rate of participation to the last European Parliament elections.

The more the needs and the expectations of large numbers of people understood by the EU, more likely it is that realistic approaches will be developed and solutions will be provided.

In this way, strengthening and increasing its effectiveness and transparency of the EU institutions through re-structuring clearly gains importance.

Within this framework, the Convention began to convene on the early days of 2002 started to discuss these subjects in turn; the distribution of power among the EU institutions and member countries, simplification of those Treaty texts, and the role of the national parliaments in the architecture of the EU.

Now, I'd like to discuss about the views and attitudes of the representatives from the member and candidate countries in the Convention about the subjects pertaining to the future of the EU.

Undoubtedly, there is a clear relationship between the views on the future of the EU and the historical experiences of the member and candidate countries. That's why the difference between the views of the member and the candidate counties upon the future of the EU that we saw at the early stage of the discussions can be regarded as normal.

In a very general sense, it can be said that there were two main views and many intermediary views some of them very close to each other on power sharing.

The first of these ideas is shared by a group of countries led mainly by member states with federative structures. The idea, which seems to be supported also by some relatively smaller member states and some of the candidate countries, revolves around:

- Strengthening of the supranational structure of the Union; 
institutions;

- Increasing the powers and responsibilities of the supranational

- Incorporating a catalogue of powers, which describes the delimitation of powers between the EU and member states, into the constitutional text.

The idea is supported especially by Germany and Greece.

The second idea is based on these perspectives:

- The Union should remain a union of nation states;

- The intergovernmental dimension should be strengthened;

- A catalogue of powers is impossible;

- Delimitation of powers through strict lines would cause further confusion in practice, and negatively affect the decision-making capacity of the EU;

- Solution should be based on institutional reform.

The abovementioned idea is supported mainly by the United Kingdom and Denmark.

Anti-federalist France proposes a model that attaches importance to the nation state, and supports the idea of "a federation of nation states" that favours further integration. Italy supports this idea, too.

The likely response to the question "Which powers should be at whose disposal and why?" shall also be the answer to the question "What kind of Europe is hoped for?"

The concern of the federalists, who support a strict delimitation of powers, is an anticipated erosion of the constitutional powers of federal structures. Some relatively smaller member states and some of the candidate countries, on the other hand, are concerned about the danger of a gradual erosion or disappearance of national identities in favour of larger members or a imaged European identity.

The opinions of countries on the future status of the "Charter of Fundamental Rights", which will be the second main item on the agenda of the upcoming IGC, differ considerably. This charter was prepared not as a legal instrument but a political declaration and adopted in Nice. It comprises new rights likely to be added to the European Convention of Human Rights, 
which in essence originate from the case law of the European Court of Human Rights.

As to the simplification of EU Treaties, differing opinions among countries still exist. As is known, the nature of the Union's acquis reflect compromises that EU Member States reached after prolonged discussions, and therefore are of a political nature. Accordingly, the difficulty in this respect is the question that how much it will be possible to both simplify the content of these documents and unify the different interests of the member states without sacrificing the meaning of these treaties.

Although there are political and legal difficulties regarding the simplification of the Treaties, the aim of those supporting simplification is to make the documents more understandable to people. In this context, it is assumed that the EU will become more accepted and shared in this way the democratic deficit could be removed.

There are different ideas on the role of national parliaments within the framework of EU. The agenda contained an item on the democratic deficit because of the lack of communication between EU institutions and the people. It has been determined that the relationship between EU parliamentarians and the European voters is not very strong.

In order to cope with this issue, EU Committees of the national parliaments should consider the draft resolutions of the EP before its final conclusion and debates should continue regarding the establishment of a second parliament with the participation from the members of national parliaments.

It seems that, it will be difficult for both parties to reach a consensus on establishing a second parliament. There have been some opinions to the effect that this parliament would make the situation even more complicated.

Some countries believe that the EU does not need any basic institutional reforms while some of them have a positive approach towards the institutional reform and emphasize that the EU institutions should be more transparent.

In order to provide peace and regional stability most of the countries would like to strengthen the Common Foreign and Security Policy. 
I would like to touch on the importance of the Convention for Turkey.

The European Union phenomenon, which is the main topic of every intellectual debate and which is seen as the key overcoming the economic distress, is in fact a subject which is generally misunderstood. The difference in perception of the EU between ordinary people and the experts has resulted with polarization.

For this reason, the Convention process will be an important step in enlightening the masses as it will involve discussions with representatives from the government, the parliament, NGOs, youth and also with the support of the media. I would like to evaluate this conference as a step in this direction.

As a participants from Turkey, we have to answer the question "what type of Union can see Turkey as a member" as well as "In What kind of Union can we participate".

Europe must demonstrate a multi - tiered framework. Members of the Union, trying to influence the decision making process while protecting their national interests. Norway rejected the membership of the Union; Denmark rejected monetary union; Ireland rejected approval of the Nice Agreement via a referendum. Germany, France and England have demonstrated different perspectives for the future of the European Union.

Turkey supports the idea that the European Union should be constructed not as a super-state but has to be developed on the values of freedom, democracy, human rights and supremacy of law together with respect to the national identities of the member states.

Moreover, Turkey takes the view that national parliaments should play a vital role in the developing future architecture of the European Union; believes that a lack of democracy can be compensated.

The European Union integration process constitutes a reference model in the international arena. Therefore, it is necessary for the Union to determine a new approach in order to fulfil the needs and expectations of citizens. 
The Union has completed the process of financial and money union, in order to increase its efficiency in the international arena and has to demonstrate more efforts to be a political Union. If the Union is able to resolve its internal problems it will prepare the basis for a new European model.

In the 21th century, the distribution of authority between the Union and the member states should be made clear.

In the globalized world, the European citizen is looking for more security and greater wealth.

It will only be possible to create more wealth and to strengthen the EU's financial and monetary structure and to improve democracy by generating and maintaining sustainable development.

Furthermore, taking the secondary and ratio principles into consideration the distribution of the authorities should be based on a system. However, the subjects like education, culture and inner administrative structures should be left to the restricted authority of the member countries. At this stage, although there should be an openness between the Union and the member countries within the framework of definite rules a restriction of authority will be bring more harm than benefit. The sharing of the authority between the Union and the member countries should be in two directions.

I want to conclude my words with a couple of sentences with respect to the relations of EU, Convention and Turkey.

Turkey obtained the right to suggest solutions for the reconstruction of the European Union and considers the sensitivities while sharing her future with the EU.

Turkey has to be directed towards the EU by protecting her own interests and discussing and realising the structural reforms. Altogether with the Government, the Opposition and the NGOs, the activities should be carried out in harmony and should reach a result that does not increase the distance between us and the other candidate countries.

Our purpose should be to reach, in the shortest run, a level that the state of development in the $21 \mathrm{st}$ century demands the one based on the principles 
of human rights, democracy and state of law. We have to accept that, without realising those values, Turkey can not become a member to the European Union. It is possible for Turkey to reach her full - membership goal by considering her own interests, discussing the structural reforms with her own values and in consensus.

EU can never sacrifice a Turkey, that has fulfilled the economic and political criteria. Turkey's participation in the formation of the new world order in Eurasia, as a model that succeeded in fulfilling the development criteria, will be a good example of the consensus of civilization. 